\title{
Analisis Konten E-Marketing Campaign JD.ID \#joychallenge Menggunakan Influencer Marketing
}

\author{
Nagia M. Asmanda ${ }^{1}$, Eko Harry Susanto ${ }^{2}$ Sudarto $^{3 *}$ \\ ${ }^{1}$ Fakultas Ilmu Komunikasi Universitas Tarumanagara, Jakarta \\ Email: nagia.915170047@stu.untar.ac.id \\ ${ }^{2}$ Fakultas Ilmu Komunikasi Universitas Tarumanagara, Jakarta \\ Email:ekos@fikom.untar.ac.id \\ ${ }^{3}$ Fakultas Ilmu Komunikasi Universitas Tarumanagara, Jakarta* \\ Email: sudarto@fikom.untar.ac.id
}

Masuk tanggal : 15-12-2021, revisi tanggal : 06-01-2022, diterima untuk diterbitkan tanggal : 16-02-2022

\begin{abstract}
Technological developments have a very broad influence in terms of business. Things that are rapidly developing in the field of information technology and business today are done online which provides many benefits and advantages when compared to offline business concepts. This concept is what some E-Commerce companies in Indonesia have. Increasing competition has resulted in every e-commerce company competing to create a campaign content in the context of an e-marketing strategy that will be conveyed to the general public in order to increase brand awareness and sales. Because researchers are interested in discussing the analysis of e-marketing content carried out by the company JD.ID, one of the leading ecommerce companies in Indonesia by carrying out the \#joychallange campaign by involving influencer marketing with the aim of research to see more deeply about the content and what is different in content. This jdid \#joychallenge campaign with campaigns presented by other e-commerce companies as well as the workings of an influencer in this campaign engaged in artistic creativity. Research using a qualitative approach with case study methods and data study methods used interviews, documentation studies, and literature studies. The results of this research can be seen that currently marketing content can be through any media, one of which is in artistic creativity, namely face painting
\end{abstract}

Keywords: business communication, e-marketing, influencer marketing, marketing content

\begin{abstract}
Abstrak
Perkembangan teknologi memberikan pengaruh yang sangat luas dalam segi bisnis. Hal yang berkembang pesat dalam bidang teknologi informasi dan bisnis saat ini yaitu dilakukan secara online yang memberikan banyak kemudahan dan kelebihan jika dibandingkan dengan konsep bisnis secara offline. Konsep inilah yang memunculkan beberapa perusahaan e-commerce di Indonesia. Persaingan pun semakin tinggi mengakibatkan setiap perushaan e-commerce berlomba-lomba untuk membuat suatu konten campaign dalam konteks strategi e-marketing yang akan di sampaikan kepada khalayak umum guna meningkatkan brand awareness dan penjualan. Karena itulah peneliti tertarik membahas mengenai analisis dari konten $e$-marketing yang dilakukan perusahaan JD.ID salah satu perusahaan e-commerce tekemuka di Indonesia dengan mengusung campaign \#joychallange dengan melibatkan influencer marketing ini dengan tujuan penelitian ini untuk mengetahui lebih dalam mengenai kotennya dan apa yang membedakan konten campaign jdid \#joychallenge ini yang disajikan oleh perusahaan $e$ commerce lainnya serta cara kerja dari seorang influencer dalam campaign yang bergerak di kreatifitas seni ini. Penelitian ini menggunakan pendekatan kualitatif dengan metode studi kasus dan metode pengumpulan data yang digunakan yaitu wawancara, studi dokumentasi, dan studi kepustakaan. Hasil dari penelitian ini yaitu konten marketing dapat menggunakan
\end{abstract}


media apapun salah satunya facepainting. Konten menggunakan facepainting dinilai memiliki keunikan sendiri dan menjadi daya tarik.

Kata Kunci: $e$-marketing, influencer marketing, komunikasi bisnis, pemasaran konten

\section{Pendahuluan}

Teknologi berkembang sangat cepat dan memiliki banyak inovasi yang memadukannya dengan komunikasi bisnis. Ini dapat kita lihat dari banyaknya bisnis yang dilakukan secara online Ini akan menciptakan sebuah revolusi pada perkembangan komunikasi dan informasi serta internet.

Revolusi pada perkembangan komunikasi ini menawarkan berbagai kemudahan sekaligus perubahan. Perubahan ini misalnya terjadi pada komunikasi pemasaran yaitu promosi dan periklanan. Internet yang dinamis dan fleksibel membuat pelaku bisnis sering mengaplikasikan ilmu Public Relations. Penerapan internet ke dalam kegiatan Public Relation memiliki beberapa keuntungan, seperti informasi yang disampaikan kepada khalayak. Selain itu, penggunaan internet juga dapat membuka kesempatan terjadinya hubungan komunikasi bidang pemasaran secara langsung (Ardianto et. al, 2012:193).

Perkembangan komunikasi dan teknologi itulah yang menciptakan bauran dari komunikasi pemasaran Word of Mouth memiliki kekuatan besar yang berdampak pada perilaku pembelian konsumen. Rekomendasi dari teman yang sudah dipercaya, asosiasi, dan konsumen lain berpotensi untuk lebih dipercaya dibandingkan dari sumber komersil, seperti iklan dan salespeople. Sebagian besar, word of mouth terjadi secara alami, konsumen mulai dengan membicarakan sebuah merek yang mereka gunakan kepada orang lain (Kotler \& Amstrong, 2012: 139).

Di Indonesia saat ini banyak sekali perusahaan yang bergerak dibidang $E$ Commerce dan sedang berlomba-lomba dalam meningkatkan Brand Awareness perusahaan mereka. Hal ini dapat kita lihat dari banyaknya campaign yang mereka buat di ranah dunia digital dengan mengajak influencer menjadi partner dalam membuat suatu campaign agar lebih menarik. Karena itulah peneliti tertarik meneliti apa bedanya konten yang dibuat oleh pihak JD.ID dengan melibatkan influencer dengan konten campaign yang di lakukan e-commerce lainnya.

Dalam melakukan penelitian ini penulis menggunkan beberapa teori untuk mendukung hasil penelitian ini, sebagai berikut :

a. Komunikasi Bisnis

Menurut Rosenblatt (Iriantara 2014: 22) komunikasi bisnis adalah pertukaran gagasan, pendapat, informasi, instruksi dan sebagainya yang memiliki tujuan tertentu yang disajikan secara personal atau impersonal melalui simbol-simbol atau sinyal-sinyal untuk mencapai tujuan organisasi.

b. Digital Activity

Ditentukannya internet sebagai tools yang menunjang dalam pelaksanaan srategi digital ini, barulah kemudian ditentukan lebih spesifik dan secara keseluruhan perencanaan seperti apa yang dilakukan dalam melaksanakan aktivitas komunikasi seperti membuat campaign secara digital serta akan membuat bagaimana digital activity menjadi suatu hal yang unik.

c. Content Creation Marketing

Content marketing adalah salah satu strategi daam komuikasi pemasaran dengan menggunakan suatu cara yang dapat menghasilkan konten 
yang bertujuan untuk memberi informasi kepada target (konsumen) yang bersifat persuasi, atas produk yang dipasarkan.

d. Influencer Marketing

Influencer adalah seorang yang mampu melihat pengikutnya sebagai sumber dari informasi, yang dimana ia menciptakan jaringan komunikasi yang kuat, dan mengakibatkan dapat keputusan orang lain dapat dipengaruhi agar menggunakan produk yang di promosikan olehnya.

e. Facepainting

Face painting adalah kata lain dari lukisan di wajah, yang bisa melukis wajah sesuai dengan keinginan mulai dari mahkluk hidup maupun benda mati, tokoh ataupun gambar. Bagi sebagian orang ada yang familiar dengan facepainting yang biasanya di gunakan untuk make up drama kolosal, drama musikal, syuting film, festival, dll.

\section{Metode Penelitian}

Pendekatan penelitian yang digunakan oleh penulis yaitu menggunakan pendekatan penelitian kualitatif. Menurut Sukmadinata (Gunawan 2013: 80), penelitian kualitatif adalah penelitian yang digunakan guna menjelaskan secara keseluruhan dan menganalisis sejumlah fenomena, peristiwa, aktivitas sosial, sikap, kepercayaan, persepsi dan orang secara individual maupun kelompok. Penelitian ini menggunakan pendekatan kualitatif dikarenakan untuk memahami fenomena konten marketing yang dilakukan dalam suatu konten kreatif campaign \#joychallange dengan metode DIY face painting, cara mendeskripsikan dan menganalisis fenomena tersebut dikaitkan dengan konsep e-marketing baru. Dalam penelitian kualitatif, studi kasus menurut Creswell (Gunawan, 2014:114) penelitian studi kasus adalah penelitian yang digunakan terhadap suatu objek, yang disebut sebagai kasus, yang dilakukan secara seutuhnya, menyeluruh dan mendalam dengan menggunakan berbagai macam sumber data.

Metode pengumpulan data yang penulis gunakan adalah wawancara, dokumentasi, dan studi kepustakaaan. Amirin berpendapat (Idrus, 2009:91) subyek penelitian merupakan seseorang atau sesuatu yang mengenainya ingin diperoleh keterangan. Sehingga subyek penelitian penulis terdiri dari enam informan yaitu satu informan dari pihak agency yang menangani campaign joychallenge dari JDID, dua influencer wanita yang ikut serta dalam campaign, serta tiga informan pendukung yang melihat campaign dan merupakan pengikut dari influencer. objeknya yaitu konten dari campaign \#joychallange dengan menggunakan kreatifitas apakah dapat memberi dampak ke masyArakat luas dan tujuan dari challenge ini tercapai.

\section{Hasil Temuan dan Diskusi}

Berdasarkan data yang sudah diperoleh penulis dengan menggunakan metode pengumpulan data berupa studi dokumentasi, studi pustaka, dan wawancara dengan enam narasumber untuk melengkapi penelitian penulis, maka dalam bagian ini penulis akan menjabarkan hasil dari penelitian yang diperoleh sebagai berikut: 


\section{Profil Campaign \#joychallenge}

Gambar 1. Profil Campaign \#joychallenge

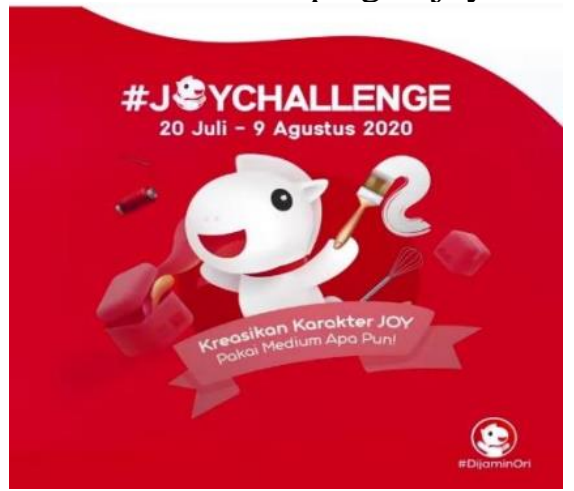

Sumber: Media Sosial Instagram JD.id

Kampanye Joychallenge merupakan sebuah digital activity dari JD.ID sebagai salah satu rangkaian rebranding JD.ID, baik dari segi logo dan juga maskot: JOY. Bertujuan menarik lebih banyak awareness tentang rebranding yang dilakukan oleh JD.ID terutama perihal maskot. Kompetisi ini mengharuskan para peserta membuat ide kreativitas (DIY concept) menggunakan medium apa pun, tetapi wajib menampilkan JOY sebagai elemen utama seperti membuat kue bergambar, melukis, bikin tote bag bergambar, facepainting dan sebagainya.

Dalam hal ini, KOL menjadi partner JD.ID dalam rangka meningkatkan awareness dari campaign joychallenge dan juga aktivitas rebranding JD.ID itu sendiri. KOL diminta untuk memberikan kontribusi dalam bentuk foto ataupun video DIY serta kreativitas masing-masing sesuai dengan expertise KOL tersebut.

\section{Strategi E-marketing dalam Konten Campaign JD.ID \#Joychallenge}

Saat ini perusahaan sudah banyak memanfaatkan internet karena karakternya yang dapat menjangkau masyarakat atau target pasar yang lebih luas. Seperti yang dilakukan perusahaan e-commerce JD.ID membuat suatu konten campaign yang menarik dan kreatif serta memiliki khas perusahannya sendiri yang memberikan warna baru dalam strategi marketing saat ini dengan menekankan pada kreatifitas yang dilakukan secara online. Seperti yang dikatakan oleh Erick sebagai mitra JD.ID dalam campaign \#joychallenge, bisa dibilang sebagai hal yang unik mengambar mascot di wajah. Biasanya orang menggambar di atas kertas, tapi JD.ID mencoba sesuatu yang baru yang belum banyak digunakan perushaan lain dalam membuat konten campaign e-marketing yang baru.

Content marketing bukan merupakan taktik, melainkan strategi. Perusahaan yang sukses menyesuaikan kebutuhan dan pertanyaan konsumen melalui muatan pesan dalam konten online berupa video atau gambar yang dihasilkan dapat meninggalkan ruang tersendiri ketempat konten tersebut disiarkan. Berikut profil dari konsep konten campaign joychallenge. 
Gambar 2. Konsep dari Campaign \#joychallenge

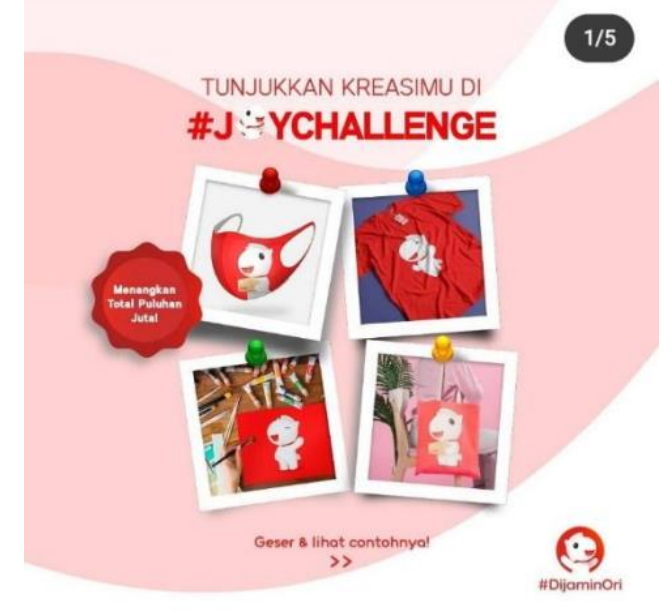

Sumber: Media Sosial Instagram JD.id

\section{Keterlibatan Influencer dalam Menyukseskan Campaign}

Adapun kegiatan yang saat ini sedang aktif di media sosial adalah membuat kampanye dengan berkolaborasi influencer sebagai mitra kerja. Influencer adalah orang yang mampu melihat orang lain sebagai sumber informasi, kemudian membuat jaringan komunikasi yang kuat, sehingga dapat mempengaruhi keputusan orang lain untuk menggunakan produk mereka bisa berupa barang atau jasa.

Pada penelitiaan ini para influencer menjabarkan pengerjaan yang dia lakukan sebagai creator campaign. Mereka menjelaskan secara detail kendala yang dihadapi, mulai dari makeup, membuat sketsa, hingga foto.

Proses pembuatan campaign memang berbeda, ada yang dibuat dengan video dan ada juga yang dibuat hanya dengan foto. Influencer mengungkapkan bahwa tingkat pengerjaan foto lebih mudah dibandingan video karena perlu waktu lagi dalam proses editing, mereka memiliki kendala yang sama seprti harus mengeksplor dalam pengerjaannya.

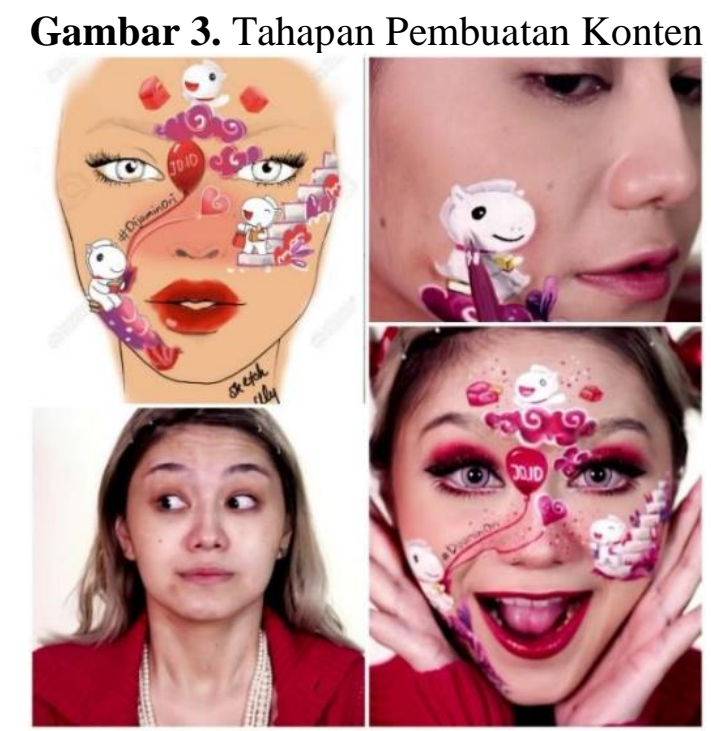

Sumber: Dokumentasi Influencer 


\section{Pemanfaaatan \#joychallenge (Facepainting) yang Dilakukan Influencer untuk JD.ID}

Pemanfaatan konten yang digunakan JD.ID dengan melibatkan influencer marketing membuat pesan yang ingin dibagikan menjadi lebih mudah dan luas. Itu bisa dijadikan sebagai media promosi ataupun untuk meningkatkan brand awrness perusahaan JD.ID kepada calon target konsumen, hal itu memiliki dampak yang besar pada perkembangan merek dan penjualan. Media sosial saat ini memberikan kemudahan bagi para pelaku usaha untuk menjangkau target pasarnya melalui konten yang menarik dengan facepainting.

Dunia pemasaran apalagi di dalam media sosial merupakan media penting untuk menyampaikan pesan agar bisa di pahami oleh banyak orang. Perusahaan JD.ID yang berpartisipasi dan membuat campaign dalam jaringan sosial serta komunitas dapaaaat dikatakan sebagai startegi viral marketing atau online yaitu dengan teori word of mouth. Komunikasi dari mulut ke mulut atau word of mouth (WOM) timbul ketika konsumen puas atas suatu produk atau sangat kecewa atas produk yang dibelinya.

Konten yang dibagikan dan pesan yang diteruskan dapat membantu meningkatkan kesadaran ketika konsumen puas. Mereka akan menceritakannya kepada konsumen lain tentang produk tersebut. Dalam konten \#joychallenge ini yang peneliti wawancarai mereka senang dengan konten ini dan dibagikannya kepada lingkungannya seperti keluarga dan teman-temannya . Influencer pun mengatakan kegiatan word of mount yang mereka kerjakan dalam campaign ini mendapatkan tanggapan yang baik dari para folowers serta insight yang di peroleh mereka terhitung baik.

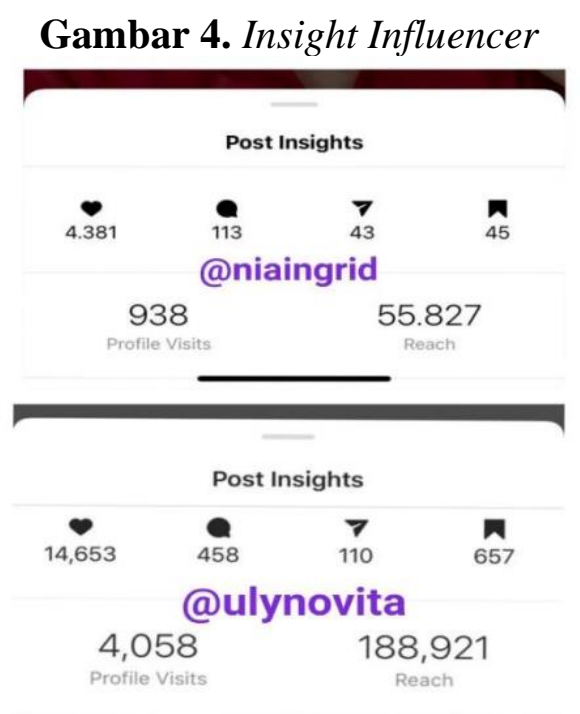

Sumber: Dokumentasi Influencer

\section{Simpulan}

Berdasarkan hasil yang di dapatkan oleh peneliti dalam penelitian ini bisa di Tarik kesimpulan sebagai berikut:

1. Konten e-marketing yang diusung oleh pihak JD.ID dalam campaign \#joychallenge bertujuan memabmgun awareness tentang rebranding yang dilakukan oleh JD.ID terutama perihal maskot. konten tersebut masuk 
2. Pihak JD.ID menggunakan agency marketing untuk mencari influencer dan berhubungan langsung dengannya dalam proses pengerjaan campaign ini.

3. Strategi JD.ID dengan menggunakan influencer sebagai partner dalam menyukseskan campaign \#joychallenge berhasil

4. JD.ID memanfaatkan konten campaign yang berfokus pada kreativitas seni yang bisa di aplikasikan di media manapun yang menarik ialah facepainting (melukis di wajah) yang diusung menjadi salah satu konsep konten.

\section{Ucapan Terima Kasih}

Peneliti ingin mengucapkan terima kasih kepada Fakultas Ilmu Komunikasi Universitas Tarumanagara, narasumber, serta semua pihak yang turut membantu peneliti sehingga penelitian ini dapat diselesaikan.

\section{Daftar Pustaka}

Ardianto Elvinaro, Soeganda Priyatna. (2009). Tujuh Pilar Strategi Konumikasi Bisnis. Bandung: Widya Padjajaran.

Gunawan, Imam. (2014). Metode Penelitian Kualitatif: Teori dan praktik. Jakarta: PT Bumi Aksara.

Idrus, Muhammad. (2009). Metode Penelitian Ilmu Sosial. Jakarta: Penerbit Erlangga. Kotler, Philip and Garry Armstrong. (2012). Prinsip-Prisip Pemasaran. Jakarta: PT Bumi Aksara.

Moleong, Lexy J. (2009). Metodologi Penelitian Kualitatif. Bandung: PT Remaja Rosdakarya.

Susanto, Eko Harry. (2014). Dinamika Pesan Iklan. Jakarta: Jurnal Komunikasi Universitas Tarumanagara

Susanto, Eko Harry. (2018). Komunikasi Manusia: Teori dan Praktik Dalam Penyampaian Gagasan. Jakarta: Mitra Wacana Media. 